\title{
RELIGIOUS TOURISM AND RELIGIOUS TOURISM RESOURCES
}

\author{
Slavi DIMITROV \\ Faculty of Economics, University of Veliko Tarnovo
}

s.dimitrov@uni-vt.bg

\begin{abstract}
Regularly motivated trips are as old as religion itself, and therefore religious tourism is the oldest type of tourism that has been in existence since ancient times. Religious tourism is a type of specialized tourism that satisfies religious and spiritual needs as well as related art, cultural and historical and other values. Religious tourism is highly developed in many countries. These countries have a rich base of religious monuments, monasteries, temples. Bulgaria also has numerous religious tourism resources, which is a prerequisite for the development of this kind of tourism. Some of the sites are under the auspices of UNESCO. These are the Rila Monastery, the Boyana Church and the Ivanovo Rock Monasteries.
\end{abstract}

Keywords: Religious tourism, tourist resources, cultural and historical heritage.

\section{Resumo}

Viagens regularmente motivadas são tão antigas quanto a própria religião e, portanto, o turismo religioso é o tipo de turismo mais antigo que existe desde a antiguidade. O turismo religioso é um tipo de turismo especializado, que satisfaz necessidades religiosas e espirituais, assim como arte relacionada, valores culturais e históricos e outros valores. Em muitos países, incluindo a Bulgária, o turismo religioso é altamente desenvolvido. Estes países têm uma rica base de monumentos religiosos, mosteiros, templos que designamos como recursos turísticos religiosos. A Bulgária também possui numerosos recursos turísticos religiosos, o que é um pré-requisito para o desenvolvimento deste tipo de turismo. Alguns dos sites estão sob os auspícios da UNESCO. Estes são o Mosteiro de Rila, a Igreja Boyana e os Mosteiros Rock Ivanovo.

Palavras-chave: Turismo religioso, recursos turísticos, patrimônio cultural e histórico.

\section{Introduction}

Regularly motivated trips are as old as religion itself, and therefore religious tourism is the oldest type of tourism that has been in existence since ancient times. Religious tourism is a modern (specialized) type of tourism. It is often intertwine, more or less, with other types of tourism. The strongest combination with cultural tourism (due to the nature of the objects who are visiting) is often determined as part of it. Its development requires religious tourism resources that are the subject of research in the present work. 


\section{Definition of Religious Tourism}

At the core of the essential characteristic of religious tourism is, as a rule, the meaning of the term "religion", and hence the definition of "religious". From the point of view of its more precise interpretation, it is necessary to compare it with other similar concepts, such as "cult". The cult is interpreted as: "religious tribute, prayer, spells, external actions, etc.; serving a deity; adoration, exalted honor, adoration "or even as" a poem, an idol, a god, a deity, a fetish, a worship, worship, exaltation, raise, worship".

The term "religion" has a broader meaning as "a form of public consciousness, a set of systems of views, attitudes and customs based on belief in supernatural powers, as well as a set of moral norms, practices, values, institutions and rituals accompanying this system". It is also defined as "an ideology, a distinctive feature of which is belief in supernatural, in gods, spirits, etc. or "religion, faith, belief, creed, dogma".

The term "religious tourism" combines the meaning of religion (cult) with tourism (tourist travel) and is most directly related to the needs and motives that the latter satisfies. It follows that clarifying the essence of religious tourism is appropriate starting from its motivational basics. An overview of some of its definitions confirms this conclusion (NESHKOV, 2008).

In his Travel, Tourism, and Hospitality Dictionary, S. Medlik defines religious tourism in a narrow sense as "trips and visits for the purpose of religious experiences, such as pilgrimage to Jerusalem, Lourdes or Mecca”, but in the broad sense „travel and visits motivated by religious heritage such as churches and cathedrals" (MEDLIK, 1996).

In the English language version of the free Wikipedia encyclopedia, religious tourism is defined as "a form of tourism where believing people travel individually or in groups for worship, mission or entertainment".

In German, religious tourism is most often mentioned to as "spiritual tourism" (Spiritual Tourism). Art History Specialist Karin Berkemann defines spiritual tourism as a "spiritual and physical journey undertaken by people seeking knowledge of the transcendental, the meaning of life and values".

The Catholic theologian Herbert Poensgen understands spiritual tourism as "that form of travel, rest and unloading, which is fueled by longing for spiritual values, healing, holism (socialization), and by the drive to the supernatural".

Marketing psychologist Christoph B. Melchers defines spiritual tourism in the widest sense as "establishing intimacy with the peculiarity", which can range from "a family image before the statue of a certain personality to a perception of the meaning of life" (MARINOV, 2011).

In the presentation of Eugenio Yunis, representative and spokesperson of the World Tourism Organization (WTO) at the International Conference on Religious Tourism (ICORET) in Nicosia, Cyprus in October 2006, religious tourism is defined in two substantive aspects: 1) Traveling pilgrims (pilgrims) and holy places, motivated by piety, spiritual fulfillment or pilgrimage; 2) Type of tourism in religious sites or places (as a variety of the cultural). Here, the narrow meaning of this concept is clearly distinguished. 
In the previously published electronic material of the First International Tradeshow \& Convention for the Religious Travel Industry in Orlando, Florida, at the end of October 2008, this type of tourism is categorically defined as "... the world's tourism market.... and an important part of the tourism industry". In a meaningful aspect, the definition includes: "travel to destinations with religious sites and places; traveling with spiritual... (NESHKOV, 2008)".

T. Hristov defines religious tourism as "types of activities related to the provision of services and the satisfaction of the needs of tourists traveling to holy places and religious centers beyond their usual environment" (HRISTOV, 2003).

Sometimes trips to religious sites are extremely long and bear all the signs of the tourist trip. Boris Vukonich gives the following definition: these are forms of tourist travel that arose as a result of the religious motivation of man (VUKONIC, 1996).

Most authors view pilgrimage tourism as a variety of religious tourism. O. Halyva (HALYVA, 2015) notes that in religious tourism many modern scholars like A. Babkin, M. Birjakov and others mention two main varieties: pilgrimage tourism and religious tourism with an excursion-cognitive orientation.

A little more broadly, he views the pilgrim tourism M. Vinokurov (VINOKUROV, 2004). In his view, pilgrimage tourism aims to visit holy places, centers, church monuments and relics. The given type of tourism implies trips for important religious ceremonies, cognitive tours for religious monuments, the history and culture of different religions, as well as scientific trips of specialists related to religious matters. This definition allows participation in pilgrimage tourism not only of believing people.

Under religious tourism, A. Babkin (BABKIN, 2008) understands the types of activities related to providing services and meeting the needs of tourists heading to holy places and religious centers beyond the usual environment. Pilgrim tourism, as defined by this author, is - a set of trips of representatives of various professions with pilgrimage purposes. Pilgrimage means the aspiration of believing people to worship in the holy places.

There is another point of view. Thus, K. Mazin considers it unacceptable to identify the terms "tourist" and "pilgrim", respectively, the terms "tourism" and "pilgrimage". Against the attribution of pilgrimage to tourism are joining by representatives of different religions.

Agreeing with K. Mazin's view of the need to allow legislative and tax preferences for religious pilgrims, it should be noted that religious pilgrimage is also the subject of research and, accordingly, is in the sphere of scientific interest (MAZIN, 2009).

Dash Ushakov's Talking Dictionary (enc-dic.com), in most cases, is defined as the journey of pilgrims to the holy places. According to D. Ushakov and S. Ozegov, the concept of "pilgrimage" has another meaning. In particular, it means a trip, walking somewhere for the purpose of acquaintance with all sights, as well as celebrity faces. Therefore, in such understanding, such trips may not be related to religious purposes.

The Sociological Dictionary notes that along with religious pilgrimage in modern society, growth and secular pilgrimage (for example, in Disneyland or Elvis Presley's mound in Memphis, Tennessee), is noted. This feature of modern tourism industry brings within itself traits of traditional pilgrimage. 
According to B. Kolev (KOLEV, 2015), pilgrimage or cult (religious tourism) can also be considered a variety of cultural and historical tourism, as its objects are very important components of the cultural and historical heritage. Cult tourism is a type of specialized tourism, including exploring, perceiving and worshiping historical values created in past historical epochs - tangible objects, temples of different kinds, lit tombs, routes, etc. Pilgrim tourism means a pilgrimage journey with a distinctly religious purpose.

A very pragmatic and comprehensive content is the definition of religious tourism by the World Religious Travel Association. According to the association, "today the religious journey and the corresponding hospitality are defined by:

- travel to religious destinations;

- travel to religious events (events);

- a mission with a mission or humanitarian purpose;

- a non-commercial trip".

St. Marinov (MARINOV, 2011) offers two brief definitions of a religious tourist and religious tourism.

A religious tourist is a person traveling and temporarily away from their usual environment to visit religious sites, sites, and events.

Religious tourism is a set of activities to meet the needs of religious travelers.

Religious tourism as a specialized species can be defined as a tourist journey motivated by the satisfaction of religious needs through the consumption of religious values (DICHEV, 2008).

According to Encho Kostov (KOSTOV, 2000), a tourist traveling with a religious purpose is a person who leaves his permanent residence for a period of no more than half a year to visit holy places or religious centers. Religious tourism is a specialized tourist trip motivated partly or entirely by religious needs, satisfied by participation in religious attractions.

We could define two distinct aspects of religious tourism:

1) Religious pilgrimage tourism, provoked by purely religious purposes, to explore God and himself;

2) Religious cultural-cognitive tourism, initiated by more general objectives related to the study of natural and cultural-historical sites related to individual religions.

Unlike all other segments of the tourist market, the main motive for religious tourism is faith. Based on the analysis of literary sources, basic research and contemporary trends in tourism development, we can synthesize a generic definition of religious tourism. Religious tourism is a specialized type of tourism where people travel individually or in groups to religious destinations beyond the limits of their usual environment for the purpose of consuming religious values in one form or another.

\section{Religious tourism resources}

The product of religious tourism includes countless many religious attractions that can be grouped in the following directions: 
(a) holy places and religious centers serving the purpose of religiously motivated pilgrimage visits;

b) religious buildings and monuments that have both historical and architectural and artistic value;

c) religious events and celebrations (festivals, processions, rituals, offices, etc.);

d) cult objects, souvenirs, sound recorders, books and others with religious themes (KOSTOV, 2001).

The American scholar Mary Nolan (NOLAN, 1992) makes the classification of religious tourist attractions in three groups:

Sanctuaries. These are temples or places where people are believed to have worked or have appeared to be important religious characters. The most numerous are those devoted to Sts. Virgin Mary, just over 2000 in Italy, Jesus Christ and others. Sacred relics and parts of clothing, relics, objects, miraculous icons are kept in some, and legends and real events enhance their attractiveness. Although there is not enough convincing scientific evidence, a number of them, like Lourdes, are curing many pilgrims with severe disabilities and illnesses.

Religious sites with complex motives to visit. They have not only a religious but also an architectural, historical, cultural-cognitive value. This group includes monasteries, most of the ancient churches, baptisteries and many of the chapels. Their dissemination is ubiquitous, and this determines their secondary, complementary role in the tourist journey.

Religious festivals and anniversaries. They are opposed to two needs: the religious one, requiring silence, privacy for the true ritual, and the tourist, with the mass presence of thousands of noisy groups. That is why they move away from the sanctuaries, they are held more in objects with valuable masterpieces of art or with particular historical fate and events. Their mass is strengthened if worship is done in the presence of a senior hierarchical officer, and especially the head of the religion (Pope John Paul II for the Catholic world, for example).

Religious sites and centers

Europe's continent is characterized by the densest network of buildings and places of pilgrimage and religious tourism. Their total number is difficult to determine, but it is enough to see the WHL, which includes 31 churches as a single object - in Tourne, Belgium; Boyana and in the village of Ivanovo in Bulgaria; Episcopal in Porec, Croatia; and in Sibenik, in the province of Trodos, Cyprus; in Green people, Sedlec Olomouc Czech Republic, etc. Not only national but also world-famous have: the cathedral in Assisi; the French in Chartres, Amiens; Cologne in Germany; Canterbury in the UK; the monasteries on the rock giants - Meteora in Greece, the Jerónimos in Lisbon, the Romanian in Horezu and a number of others. The specific value is: the pilgrimage path of St. Jacob in France; the respective church in Santiago de Compostela, Spain, and the path of pilgrims beside her.

Most are the religious sites in Italy and Spain, which is explained by their great religiosity and the specific role of the Vatican. The main Italian centers of pilgrimage are: Loreto - 4.0 million, Assisi 4 million, Rome with Vatican - 7 million, Padua - 4.6 million, Siena, Neutno to Rome, and their total number is 450, of which 112 are of international importance. By age, the XIX and XX centuries prevail with 91 centers; from the Baroque period (1600-1800) -163 centers; and the Gothic (XII - XV century) - 
84 centers. For France, the same ranking is held by Parisian Virgin Mary - 8 million people, Lourdes 5 million people, "Saint Bogorodica from Furviere" in Lyon - also 5 million people, in Marseilles - 1.5 million people, the Lijsio pilgrimage center - 1.2 million people. It is interesting that 717 trains travel to Lourd, a city with 17,000 inhabitants, its airport accommodates 530 thousand passengers (for comparison - Varna has 520 thousand passengers) and the accommodation base in hotels, catholic boarding houses and others reaches 36 thousands of beds, that is, 2.1 beds per inhabitant. In Poland, more than 4 million pilgrims visit the churches and monasteries of Yasna Gura Hill near Czestochowa, and the other larger pilgrimage centers are Lichén, Gura Sveta Anna, Piskara Słonski and others.

The specific religious significance of the most famous and tourist most attractive pilgrimage centers is expressed in:

Austria. The established center of pilgrimage is Mariahilf, located in the Eastern Alps, between Graz and Vienna. It is situated at $862 \mathrm{~m}$ which is why it is also visited as a winter resort. Its main church dates from the 11th century.

Bosnia and Herzegovina. In 1981, a group of six children from Intergroup reported the appearance of the Virgin Mary, specifically in the village of Biaakovichi on June 24th. On the third day here come 1000 people and the fifth - 15000 . Now the number of pilgrims exceeds 1.2 million people. The appearance continues, and the worshipers seek religious mercy in the church "St. Jacob" in the city (MARKOV, 2015).

Greece. Sveta Gora. Monasteries of Mount Athos. The first settler monks came to Mount Athos in the 5th century, but a more settled settlement began in the 7th century. In the short period (9631050) 150 monasteries were built in Mount Athos. Of 190 monasteries and over 12,000 monks, there are now 20 monasteries on Mount Athos, about 600 cells with just over 3,800 monks. Of the monasteries Bulgarian is only "Zograph", Serbian is "Hilendar", Russian - „St. Pantaleimon”. The remaining 17 are Greek (ALEXIEVA, 2007).

Great Britain. Westminster Abbey has the highest number of pilgrims (3.25 million people). Since 1066, all English kings have been crowned and buried here. The Coronation Corridor and the Royal Chapel are on display. Includes: octagonal Gothic cathedral of the 13th century, abbey museum, tombs of the most important British figures - Newton, Darwin, Dickens, Churchill, etc. Located on the north bank of the Thames near Buckingham Palace and „Trafalgar Square”.

Germany. In southern Bavaria, a hundred kilometers east of Munich, is Altoying, the leading pilgrimage center of the whole country. The first worship was in 1483 in the Gannen Chapel. Against him there is the church "St. Philip and Jacob" with its renowned treasure from 1400 and the magnificent panorama of 1902 - „The Crucifixion of Christ”, with an area of $1200 \mathrm{~m}^{2}$ (MARKOV, 2015). The tourist flow between Germany and Austria and the Netherlands and Germany is most powerful, due to their territorial proximity and the lack of a language barrier (LEVKOV, 2015b).

Spain. The most important is the pilgrimage path of St. Jacob coming from France, through Burgos and Leon, to Santiago de Compostela. There is also a coastal route along the Bay of Biscay (DIMITROVA, 2015). It passes through many monasteries, churches and inns, with a total length of $800 \mathrm{~km}$. In the city itself, some of the pilgrims (up to 7-8 thousand people) come on foot, bicycle or horse, as in the Middle Ages. The pilgrimage ends in the majestic cathedral where the tomb of the 
saint is the protector of all of Spain. Approximately 3 million people visit each year. More than one and a half million of them are pilgrims in the largest church-monastery complex Montserrat, $30 \mathrm{~km}$ west of Barcelona. It was built in the 11th century and its last restoration was from the 19th century. The surrounding landscape is extremely beautiful, with huge rock figures like fortress towers (MARKOV, 2015).

Italy. The Vatican is located in the western part of Rome. It is a papal sovereign city state, the residence of the Roman pope. The architectural complex of the Vatican includes cult, palace and fortress buildings. The Vatican is the largest Catholic cathedral in the world "St. Peter" (VELIKOV, 2009) and one of the main sacred places of Catholicism ${ }^{1}$. In Padua there is the Basilica of St. Antony of 1231 and the nearby Healing Baths of Evgenia, with the sanctuary of St. Virgin Mary. Near the eastern coast is the town of Loreto, which is the "holy house" of the Virgin of Nazareth. According to legends, it was carried here on the wings of angels, and more credibly aboard a crusader ship. The other important pilgrimage center, Assisi, is located north of Rome, with a basilica and monastery dating back to the 13th century dedicated to the patron saint of all of Italy St. Francis. Each year, on January 1 , the official symphonic concert shown by televisions is shown to 300 million viewers.

Poland. Apart from the mentioned churches and monasteries devoted to Sts. Virgin Mary in Czestochowa, a large pilgrimage stream (of over 1 million people) is headed to Liechen. In August, more than 300,000 people come to Czestochowa to worship the miraculous icon of St. Virgin Mary. Many of them hope through prayers to receive healing. Large processions and liturgies are organized in front of 500,000 people (MARKOV, 2015).

Portugal. Fátima is a place of worship similar to Lourdes, which is also visited by patients in the hope of being healed ${ }^{2}$. In 1919 a chapel was built in the holy place, which in 1922 was destroyed by an explosion in an attack. In 1928 the bishop of the city of Leiria aid the foundation stone of a church and sanctuary, completed in 1930, the large building was in the neoclassic style. Here are the tombs of the two shepherds Francisco e Jacinta Marto. The third shepherd Lúcia dos Santos died in 2005 in Coimbra at the age of 98 .

John Paul II himself has visited Fátima 3 times. There, on 13 May 2000, he declared a Jacinta and Francisco Marto as blissful. Every year, from May 13 to late October, pilgrims from the entire

\footnotetext{
${ }^{1}$ According to Catholic tradition, the church is buried in the church. Peter, one of the twelve apostles of Jesus Christ, considered by the Catholics to be the first bishop of Rome and the first in the list of Roman pope. The Christian church has also existed since the IV century, and the construction of the modern building began on 18 April 1506 and was completed on 18 November 1626.

2 According to the legend of May 13,1917, Virgin Mary appears to the three children of a local shepherd, Lúcia dos Santos, Jacinta Marto and Francisco, in the middle of the field. She tells them they have to go back to this place on the 13th of the month. The children agreed to keep a confidential meeting with God's mother, but Jacinta violated the agreement and on 13 July the place was visited by some curious people who wanted to convince themselves with the eyes of the children's story. In the following months, the number of people who cheated with the story grew more and more until God's mother announced that a miracle would happen on October 13. At the appointed day, thousands witnessed the „Sunshine Miracle”. People could no trouble watching the sun, which resembled a silver disk and spun like a fiery ball.

On May 13, 1930, the bishop of Leiria declared the phenomenon true and the official worship of the Virgin Mary in Fátima was permitted. During the third appearance on July 13, the three children were bequeathed to the three secrets of Fátima. In 1941, Lúcia, one of the three children and the only living (the other two victims of the Spanish flu), recorded the first and the second, and in 1944 the third. Some refer to the content of the secret to the assassination of Papa John Paul II on 13 May 1981, which was done on the day of the first appearance of Our Lady.
} 
Catholic world are coming to Fátima. This contributes to the development of religious tourism, all the more so since Fátima begins the pilgrim's pilgrimage path to Santiago de Compostela (DIMITROV, 2014).

France. Together with the mentioned main pilgrimage center, Lourdes, from 1859 stand out Mon-sen Michelle and Lizzie. The first one also has an important economic role, with an annual revenue of nearly EUR 700 million. The island monastery fortress Mont-des-Michel has a smaller bed base in hotels around 1200 beds and over 700 in campsites, and in Lisieux there are 1160 beds in hotels and 280 in campsites accommodating 1.5 million tourists.

United States. Significant are the opportunities for development of this type of tourism in the US, especially in the historical regions - New England and the Middle-Atlantic States (LEVKOV, 2015a).

Travel and Leisure specializes in the 40 most visited holy places in the world. Here are included temples of different religions - Christianity, Buddhism, Islam, Judaism, and others. The ranking of the most visited holy places looks like this in recent years by an average number of visitors (pilgrims and tourists):

1. Shijo Temple Meiji in Tokyo - visited by about 30 million people a year (Shinto is a traditional religion in Japan only and precedes the emergence of Buddhism in this country). It was built 100 years ago in honor of Emperor Meiji and Empress Shaken. Surrounded by a forest of over 100,000 trees and beautiful gardens.

2. Sensoji Buddhist Temple in Tokyo - 30 million people. Built in honor of Buddha Kanon.

3. Kashi Vishwanta in Varanasi (India) - 21.9 million people. It is located on the west bank of the Ganges River and is the most famous Hindu temple dedicated to Lord Shiva in Varanasi.

4. Catholic bases Nuestra Señora de Guadalupe in Mexico City - 20 million people. Thousands come here to visit the liturgy and see the image of Our Lady, which is alleged to have appeared on its own on a canvas in 1531.

5. The Hindu Temple of Tirumala Tirupati Devastanamas in Andhra Pradesh, India - 18.25 million people. Hindu sects began building this temple 1200 years ago.

6. Notre Dame Cathedral in Paris - 13.6 million people. It was built in 1345 and is the most visited site in Europe.

7. Sacre Coeur Basilica, Paris - 10.5 million people. On this hill, initially druids worshiped their gods Mercury and Mars. Today a beautiful 19th-century basilica towers overlooking Paris.

8. Buddhist temple Naritasan Shinchogji in Chiba Prefecture, Japan - 10 million people. It was built in 940 .

9. The Shintoi Temple, Tsurugaoka Hachimangu, in the Kanagawa Prefecture, Japan - 10 million people. It was built in honor of the God of War in the 12th century.

10. Kumidzuwara Buddhist Temple in Kyoto (Japan) - 10 million people. It is known as a temple of pure water and is protected by UNESCO.

11. Shinto Temple Ise Jingfu, in Isse, Japan - 8.5 million people. The forest here is worshiped as sacred before it began building a temple in the 3rd century AD. 
12. St. Peter's Basilica, Vatican City - 7 million people. One of the most famous buildings in the world. Here are some of the most famous Renaissance masters like Rafaello, Bernini, Michelangelo and others. Under the protection of UNESCO.

13. Dazaifu Tenangu Temple (Japan) - 6.6 million people.

14. Buddhist Kinkaku-shi Temple in Kyoto (Japan), built in the 15th century - 6 million people.

15. Cologne Cathedral (Germany), under the protection of UNESCO - 6 million people.

The list is dominated by Japanese and other eastern temples. It is noteworthy that many famous cathedrals and mosques are located outside the top 20. The Sistine Chapel in Rome, for example, is only 24th with 4 million people a year. Hagia Sophia in Istanbul is 29th with 2.9 million people a year. The largest Muslim temple in the world The sacred Al-Haram Mosque in Mecca, whose yard is the famous black stone of Kaaba, is only 30th. Sagrada Familia in Barcelona is 31st (2.3 million people). Jerusalem appears only in 19th place with the Wailing Wall. This ranking by number of visitors (pilgrims and tourists) over time changes, but basically preserves the arrangement of the sanctuaries and temples (KOLEV, 2017).

Probably the data on the attendance of the 15 temples is somewhat surprising because most people, both in Bulgaria and in Europe, are accustomed to accepting that one of the largest, most valuable and world-renowned religious sites are on our continent. These data show another and perhaps a bit surprising picture. There is hardly a lot of people, for example, aware of the Japanese temples mentioned above, which lead the presented rankings by degree of attendance. Explanations of these facts can also be sought. One of them is the very large number of the population of India, Mexico and Japan, as well as their preserved national and religious traditions. Another explanation may be based on the fact that in these three countries the degree of religiosity is much greater than that of the European peoples, which forms flows mainly made up of tourists and fewer pilgrims looking for sincere religious experiences and emotions. The high attendance of the listed temples in Japan and India is not a one-time action, but an annual traditional pilgrimage practice. This explains the extraordinary number of pilgrims.

Bulgaria has experienced a nearly half-century period of atheism and restricting religious tourism, and such large pilgrimage centers have not been established. Of the 160 monasteries most visited are Rilski, Bachkovski, Troyanski, Arapovski. Cross Forest also attracts many visitors. Among the 1245 churches of cultural significance tourist interest is shown to "Al. Nevski" - Sofia, Shipka, Pazardzhik, Samokov, Veliko Tarnovo and others. For the Catholic religion this is the temple "St. Ludwig" in Plovdiv, and for the Muslim - "Tombul Mosque" in Shumen (MARKOV, 2015).

Three of the Bulgarian sites included in the UNESCO List of World Natural and Cultural Heritage are Orthodox temples - the Boyana Church, since 1979, the Ivanovo Rock Monasteries of the Roussenski Lom River, from 1979 and the Rila Monastery since 1983. This is a high recognition of the world cultural and historical significance of these sites (KOLEV, 2017).

Despite its undeniable cultural heritage, Bulgaria can offer much more for the development of this type of tourism (LEVKOV, 2017). 


\section{Conclusion}

Religious tourism develops as a modern type of tourism, inseparably linked to cultural tourism but having its own peculiarities. An important condition for its development is the presence of religious attractions and the ability of the subjective factor to transform them into tourist products. In this area, countries developing religious tourism should be targeted, and of course Bulgaria, which is also rich in religious tourism resources.

\section{References}

ALEXIEVA, Jor., St. STAMOV. (2006). Specialized types of tourism. Part One. Publishing House „Kota, Stara Zagora.

BABKIN, A. V., (2008). Special types of tourism. -Rust-on-Don: Phoenix.

DICHEV, D., (2008). Religious values and tourist trips. -B: Religious Tourism. Monasteries - Bearers of Bulgarian Spirituality. Black Sea Economic Forum, Varna.

DIMITROV, S., (2014). Alentejo: the Land of Bread, Wine and Olive Oil. -In: Almanac „30 Years Department of „Geography” in Veliko Tarnovo University „St. St. Cyril and Methodius”, Veliko Tarnovo.

DIMITROVA, T., (2015). The dictatorship of General Primo de Rivera goes back on the road to democracy. Publishing House „Faber“, Veliko Tarnovo.

HALYVA, O. A., (2015). Sociocultural and legal grounds for the development of cultural tourism // Humanitarian reports of TSPU them. L.N. Tolstogol - №1 (13).

HRISTOV, T., (2003). Religious tourism. Moscow: Academy.

KOLEV, B., (2015). Cult tourism. Publishing House „Neofit Rilski”, Blagoevgrad.

KOLEV, B., (2017). Major and most visited cult and religious sites. -In: Proceedings of the 65th Anniversary of Prof. Markov, Publishing House „Faber”, Veliko Tarnovo, 2017.

KOSTOV, E., (2000). Religious tourism of Bulgaria - yesterday, today and tomorrow. UNWE, Sofia.

KOSTOV, E., (2001). Cultural tourism. University Publishing House „Holding”, Sofia.

LEVKOV, Kr., (2015a). Tourism in the USA - contemporary state, tendencies, problems. New Knowledge Journal of Science, Academic Publishing House „Talent“, Plovdiv, №1/, pp. 34-44.

LEVKOV, Kr., (2015b). Tourism in the EU. New Knowledge Journal of Science, Academic Publishing House „Talent”, Plovdiv, №3/, pp. 37-46.

LEVKOV, Kr., (2017). Bulgaria's place in world tourism (an attempt to positioning). New Knowledge Journal of Science, Academic Publishing House „Talent”, Plovdiv, №1, pp. 151-162.

MARINOV, St., (2011). Modern Tourism Types. Publishing House "Science and Economics”, University of Economics - Varna.

MARKOV, Iv., N. Apostolov. (2015). Tourist resources. Publishing House „Astarta”, Plovdiv. 
MAZIN, K. A., (2009). Pilgrimage and religious tourism: a comparison through the prism of millennia // Modern problems of service and tourism - №4.

MEDLIK. S., (1996). Dictionary of Travel, Tourism and Hospitality. Butterworth-Heinemann Oxford.

NOLAN, M., (1992). Religios sites as tourism attraction. - Annals of Tourism Research. №1.

NESHKOV, M., (2008). Religious tourism - emergence, essence and modern forms. -In: Religious Tourism. Monasteries - Bearers of Bulgarian Spirituality. Black Sea Economic Forum, Varna.

VELIKOV, V., (2009). International Tourism. Publishing House „Matcom”, Sofia.

VINOKUROV, M. A., (2004). What is tourism? // Izvestiya of the Irkutsk State Economic Academy. №3.

VUKONIC, B., (1996). Tourism and Religion. „Elsevier Science”. London.

http://enc-dic.com/word/p/Palomnichestvo-34791.html 